\title{
A critical moment: 25 years of Gender, Work and Organization
}

\author{
Alison Pullen, Patricia Lewis and Banu Ozkazanc-Pan
}

Sydney, Kent and Boston January 2019

Gender has been a major and recurring theme of contemporary research in the whole range of disciplines concerned with the study of work and organization. (Knights and Rubery, 1994, Editor's Introduction, Gender, Work and Organization, vol. 1, no.1, page 1)

It has become difficult to name one's feminism by a single adjective - or even to insist in every circumstance upon the noun. Consciousness of exclusion through naming is acute. Identities seem contradictory, partial and strategic (Donna Haraway, A Manifesto for Cyborgs: Science, Technology and Socialist Feminism in the 1980s, in Linda Nicolson, (1990) Feminism/Postmodernism. New York: Routledge. Pp.193194)

The relationship between Woman - a cultural and ideological composite Other constructed through diverse representational dis- course (scientific, literary, juridical, linguistic, cinematic, etc.)- and women --real, material subjects of their collective histories - is one of the central questions the practice of feminist scholarship seeks to address. (Chandra Talpade Mohanty, 1988, Under Western Eyes: Feminist Scholarship and Western Discourses, Feminist Review, 30(1): 61-88, p. 62) 


\section{Opening}

Upon its founding twenty-five years ago, Gender, Work and Organization, was the first journal of its kind on account of its focus on multi-disciplinarily informed studies of gender, work and organization coupled with a desire to develop theory and present empirical research. Its success and rapid growth trajectory over the years can be attributed to the fact that these original aims have not changed but now take shape in the context of new social, cultural, and political transformations. This anniversary issue houses the first editorial that we write as the current editorial team, and we do so in full recognition that in 1994, none of us were working in this field. Reading the founding editors' accounts as presented in that very first issue of the journal, we became conscious of the subtleties of the journal's purpose and their continued relevance for today's world. Looking back on the way the journal developed in Manchester in the United Kingdom, we rely on the memories of the founders and contributors of that first issue, and also of eminent scholars who ask: what future engagements are required in the pages of this esteemed journal?

We are truly grateful to the founding editors for their vision, and for the ways in which the journal has been central in creating the possibilities for our writing, ideas and our academic identities since we each discovered the journal - for Alison and Banu this was during the course of their doctoral studies and for Patricia it was when she moved to the UK in the 1990s. Writing this editorial is also an occasion for us to reflect on where our work would (or wouldn't!) be without the informing, motivating and legitimising role that Gender, Work and Organization provided to us as budding gender researchers and feminist scholars. Finding ourselves, at this stage of our lives, as editors of the journal, it is not without a sense of both debt and honour that we present this $25^{\text {th }}$ anniversary issue.

In introducing the papers that comprise the issue we take it as our task to also offer reflections on the journal's achievements to date as well as to anticipate its future directions and present what, to our thinking, are the possible questions that might be asked and contributors that might be made going forward. But, before doing so we thank founding editors David Knights and Jill Rubery, and immediate past editors Deborah Kerfoot and Ida Sabelis, for their leadership and initiative, Nicola Nixon for managing the journal, and the publishers Wiley. We also extend our sincere thanks to our sterling associate editors, new book review editors, social media editor and editorial board members, and the many 
reviewers and authors without whom the journal would not be possible. Currently our team is well supported by Kamali Arumugam, Amy Joint, Brian Collins and Anna O’Brien of Wiley. When the first issue was printed in 1994, critical forms of academic practice and scholarly research were in the process of infiltrating organization and management studies more generally. Many academics of the time were reading philosophy and introducing critical theory to cutting-edge programmes in their institutions, in turn shaping our community often in radical ways. In the first issue Knights and Rubery testified that: 'The journal is dedicated to advancing theory, research and applications concerning gender relations at work, the organization of gender and the gendering of organizations' (Knights and Rubery, 1994: 1).

The first contributions were Marian Court's 'Removing Macho Management: Lessons from the Field of Education', which examined discourses of management and leadership in the light of gender inequalities in social relations and in educational administration in New Zealand. From interviews with women working in primary and secondary schools, Court shows the importance of women's experience for the critique of masculinist managerial perspectives and provided early impetus for developing alternative models of leadership. Linda Hantrais and Pat Walters' 'Making It in and Making Out: Women in Professional Occupations in Britain and France' demonstrated the importance of comparative case research. In the article, they showed how the relationship between gender, work and organization in professional occupations varied according to different work environments and national contexts. Through their study of the career patterns of women in chartered accountancy and law in Britain and France, Hantrais and Walters analysed different types of organization to determine whether the societal structuring of these occupations are gendered and whether women fare better in small professional practices or large bureaucratic organizations. David Collinson and Jeff Hearn's 'Naming Men as Men: Implications for Work, Organization and Management' offered a critical analysis of gendered power relations in organizations by focusing on men and masculinities; matters often hidden and taken for granted at that time. Importantly, their concept of 'multiple masculinities' addressed issues of sameness, difference and the interrelations between men and masculinities.

Revisiting this first issue offers a welcome reminder of the importance of contextually sensitive and politically salient empirical studies, as well as the need for the journal to represent diverse geo-political knowledge. The relationship between organization and gender 
requires a responsibility to embrace the complexities, differences and fluidities of the social and interpersonal relations that produce gendered organising and organization (Acker, 1998). The gendered lives of organizational members reproduce many of the patterns of the past, and we are reminded of the need for future scholarship to embrace the political potential of diversity and difference to render organizations accountable and responsible for change.

By today, critical approaches to studying management and organization studies have become less marginalised and less radical. This serves as an important occasion for us, as the editors of this journal to reflect on the nature and futures of critical scholarship in Gender, Work and Organization. In so doing, we cannot underestimate the importance of history in understanding the context in which we write about gendered relations, power and identities especially in terms of who and what is written out of the pages of our journal. Gender studies and feminist philosophy and practice can now be found in the most conservative of journals, albeit not on a regular basis, and the boundaries between different disciplines have become more malleable when it comes to publishing gender research across different fields. There are many more journals in the market, and new journals with open access platforms are more present. This burgeoning interest in gender research and journals may suggest that gender journals have become both mainstream and profitable. In the mix of this, Gender, Work and Organization has become a leading outlet for work in in women studies, gender studies as well as offering a space for critical studies of work and organization, but in what way might this yield valuable theoretical insights and possibilities for political change in the future?

In the Aims and Scope of the journal, drafted by the founding editors, it is stated that Gender, Work and Organization welcomes 'theory-driven papers and empirical papers that go beyond mere description, using data as a means of advancing or reflecting upon theory'. Theoretical reflection and contribution are important issues when considering whether a paper can be published in Gender, Work and Organization. While this may seem an obvious point to make within the context of an academic journal, it is important to reiterate, to quote Runte \& Mills (2006: 696), theories '... provide the stories by which we come to understand the world and our place within it'. However, theories do more than give meaning to our world, they also shape our social reality. Sociology scholars (e.g. Callon, 2007) and management researchers (e.g. Ferraro et al, 2005, 2009) argue that theories are performative such that they are actively involved in the constitution of the worlds they describe and do not exist outside 
of them. Theories provide a language which influences how we view and understand the world, they can transform the social norms that impact on individual behaviour and effect institutional and organizational arrangements by reflecting the tenets of a particular theoretical viewpoint. Thus, the possibility of a theory becoming "true" increases if people take-up and act on its assumptions, put in place practices, routines and organizational arrangements that reflect theoretical ideas thereby creating the conditions that favour the predictions of a theory (Ferraro et al, 2005: 12). A case in point in the gender field is Lewis and Simpson's (2017) analysis of the performative effect of Catherine Hakim's Preference Theory. They argue that this theory is not just reflective of the specific cultural and historical circumstances of postfeminism within which it developed but that preference theory is also generative of postfeminist outcomes and values. Taken up by governments and used as the basis for policies on women, work and childcare, Hakim's preference theory constitutes the 'conditions of possibility' for women's (non)engagement in the labour force through the way in which it privileges "choosing" as the reason for women's work-life experience, foreclosing other explanations. Nevertheless, while recognising how theories can shape social reality, we should also be aware that what a theory "does" as a form of action is never "finished". How ideas circulate and the purchase they secure is crucial and so as Ahmed (2006: 105) argues we need to follow them around to assess 'how they move as well as how they get stuck'. Recognising the performativity of theory means that our responsibilities as academics goes beyond providing meaning and interpretation of empirical situations but also to reflect on the practical consequences (intended and unintended) of our work (Ferraro et al, 2009). Thus, in addition to explaining how the theories we draw on constitute social reality, critically reflecting on how these theories should mould the world we live in is necessary such that they lead to enhancement and change as opposed to maintenance of the status quo (Marti \& Scherer, 2016). This means that the theories we draw on and/or construct matter not only for the stories they tell but also for the values and ideologies they represent. As Ferraro et al (2009: 674) state: 'All of this means that we have the opportunity to both envision and create a different and maybe even better, more humane and just world'. 


\section{When theory is not enough}

Despite critical research being mainstreamed in many institutions of Western academe, we are mindful that this position is at risk for us with critical scholarship being eliminated from business schools and management schools (Parker, 2014) as top-down university changes dictate programmes informed by an ideologically narrow response to what is perceived as a customer driven economy of students and employers. Employability, skills driven courses and flexible and achievable course assessment which enable students to work (often more than part-time) while they study full-time are hallmarks of much contemporary business education. We are also witnessing the termination of gender studies in some universities, as we have seen recently in Hungary despite global resistance. Moreover, where critical theory and critical gender is still present, it is largely in Western academic institutions.

We enter 2019 feeling that we are at a moment in time where standing back and watching the academy changing at around us, means that as a journal we need to be responsive to these changes and the risks they embody. It is by doing so that that Gender, Work and Organization can remain a dynamic space for the study of gendered relations with all their difference and multiplicity. Further, we witness that despite the changes we are seeing in the nature of work and organizing, equality for women+ is not part of this. Still stubbornly present is widespread gender pay inequality, barriers to work opportunities and career advancement for women, and high levels of physical and symbolic violence against women at work. Many authors who publish in this journal have told us time and time again that gender scholars have much more work to do on labour, the market, and organizations and it seems that the interface between the journal and theory, and between the journal and practice requires special attention as we move forward.

The context in which we work needs to be considered. Marina Warner warns us of "the new brutalism in academia" (Diary, London Review of Books 36:17, September 11, 2014), and Henry Giroux (2014) states: "The corporate university is the ultimate expression of neoliberal values and social relations, which are defined by a top-down authoritarian style of power". He continues: "Education under neoliberalism is a form of radical depoliticization, one that kills the radical imagination and the hope for a world that is more just equal, and democratic society" (https://truthout.org/articles/henry-a-giroux-neoliberalism-democracy-and-theuniversity-as-a-public-sphere/). What is apparent is that individuals and groups struggling for 
equality against neoliberal forces face increasing pressure, as evinced by Nancy Fraser (2013). Women are subordinated in new ways in such contexts and it is obvious to state that academics working in some disciplines - for example diversity scholars and feminists - are more at risk of precarity than others. Criticizing the forces of domination is important, but it does not go far enough. We must move beyond pointless denunciations and offer instead a language that moves forward with the knowledge, skills, and social relations necessary for the creation of new modes of agency, social movements, and democratic economic and social policies (Giroux, 2014 https://truthout.org/articles/henry-a-giroux-neoliberalism-democracyand-the-university-as-a-public-sphere/).

Whilst theory is vital for the continuation of our field of research, in such times it is not enough. As Rhodes, Wright and Pullen remind us, academic activism 'serves to politicize scholarly work by democratically disrupting political consensus in the name of equality' They make the argument that academic activists need 'to act in the name of equality whilst resisting and contesting an academic administration whose police actions have attempted to eliminate such forms of democratic practice from the political consensus' (2018: 139). Our activism as gender scholars is one means to achieve such a politicisation of theory, and to do so with the tools of critical thought. This task requires us to embody and enact a politics that can unsettle the very structures that we live and work in. That this ethico-political work falls unequally on women and those people in precarious employment positions requires redress. This responsibility needs to be also foisted on organizations so as to bring about meaningful institutional change that goes, beyond just addressing equal representation, and moves towards exploring the subtle relations that shape the ways in which diversity is understood, and the ways in which discrimination and harassment is addressed directly. Unprecedented resistance to sexual harassment and inequality is abound in socio-political movements like \#MeToo and \#BLM that are starting to 'go global'. And as Google employees demonstrated in 2018, we are witnessing the political possibilities for overt resistance to the culture of harassment, with the unprecedented act of 20,000 people walking out of Google offices in fifty cities to protest the company's lack of action against sexual misconduct (Levin, 2018).

\section{Reflecting and anticipating}

This anniversary issue starts with the reflection of Jill Rubery and David Knights, the founding editors, whose career long contributions continue to inform submissions to the journal. Jill starts the issue reflecting on her career as a political economist, and her influence 
on the journal as a researcher using comparative institutional approaches to study the role of gender in shaping employment regimes across nation states. Jill historically reviews the influence of scholarship of gender and the macro economic and social order, and its influence on the growth of comparative research into varieties of gendered employment and welfare systems through the journal volumes. Her work encourages us to think about the specificities of gender and the law, gender and organization, gender, skills and segregation, and equality policies. In looking forward, she acknowledges areas of further attention including critical diversity studies and intersectionality (see also, Holvino (2010)). Importantly, caution is presented to call for further work on gender to continue as Jill acknowledges that gender research in many disciplines is still far from mainstreamed and falls to a minority of scholars, mainly women. This attests to Gender, Work and Organization's role in highlighting the central importance of gender research. Jill also suggests that the visibility and popularity of speaking out via the \#MeToo movement has energised the field and she sees this as an opportunity to build the gender research, both in terms of initiating new streams of scholarship but also regenerating perhaps neglected areas of analysis.

Next David Knights reflects on his long editorship of the journal, his aims and ambitions, and issues of notable interest to the field as we mark the 25th anniversary. Interestingly David notes that he wanted 'organisation' 'to convey the dynamic and processual nature of organizing rather than the concrete sense of our topic being the finite entities known as organizations' (INSERT PAGE). He also explores the importance of not taking the masculine nature of organization for granted, and tracks his work in this field to show the ways in which Gender, Work and Organization became known for masculinity research as well as labour research. David's research on masculinity demonstrates the continuing toxicity of discourses and practices of masculinity and concludes with call of arms: "we need to find new ways of resisting them whilst preserving the values of academia as an embodied, communal and ethical way of life. If this limited resistance can be mobilised in the direction of building embodied, ethically engaged academic communities as articulated by posthumanist feminists, future generations might see university's current masculine preoccupations as merely an historical blip" (INSERT PAGE NUMBER). We have been warned!

As De Coster and Zanoni's (2018) research of women academics shows, women have a symbolic struggle to (dis)identify with masculine professional norms. Here they locate 'power in the gendered relations of accountability towards multiple others', and reconceptualize gender as 'an ontological struggle in the constitution of the self as moral along 
gendered norms' (page). Importantly the ethics required in such a struggle focuses on 'the emergence of open and responsive subjectivities in relations of accountability'. For them, community and working differently become potential ways to challenge the grip of capitalism on scholarship, a pressing concern shared by many of us.

The issue then turns to Jeff Hearn's article 'Gender, Work and Organization: A GenderWork-Organization Analysis' which recollects not only the inception of the journal and Jeff's own role in it, but importantly explores how gender, work, and organization - have all become more problematic: 'just as the field of gender and organizations has become more legitimate at the overlapping of gender studies and organization studies, so the concept of 'gender' has itself become more complex, more contested, less certain' (INSERT PAGE). In thinking through what the future of gender, work and organization may look like as he raises the forms and relations of gender, sexuality and intersectionalities, including global inequalities of various kinds, persistence of (sexual) violence, and population ageing.

The anniversary issue then presents Silvia Gherardi's inspirational keynote address presented at the Gender, Work and Organization conference held in Sydney in June 2018 entitled 'If we practice posthumanist research, do we need 'gender' any longer? This provocative questions invites us to consider the ways in which future theorizing enables a critical reflection of the times in which we live, and how this might be done in the form of a joyously playful, affective, subversive textual journey. Not taking for granted the relationship between knower and known, Silvia weaves between Barad and Deleuze to consider the concept of gender and "“the forces it needs to return to life" (Deleuze and Guattari, 1991/1994, p. 28) or whether now is the moment to leave it behind' (INSERT PAGE). Developing 'posthumanist' thought and practice within the 'post-qualitative' methodologies tradition, Silvia illustrates how gender can embodied or left behind in favour of alternative theory, affect and forms. Gender is seen as a 'concept as/instead of method' line of thought. There are no answers but embodied challenges for a precarious future which requires theoretical, political and affectual address.

\section{Feminist Frontiers}

This 25th Anniversary issue of the journal launches our new Feminist Frontiers section. This section asks what radical possibilities for change are there in practice and theory? This is a time where gender studies, and women around the world, are under threat, but also one where our resistance is more visible than ever. This new section of the journal calls for the 
mobilization of diverse disciplines and people to challenge the violence around us and demand a future that is worth living. This starts in our own universities, our research teams and homes.... and we hope that the pages of Gender, Work and Organization are a space for the changes we want to see. We are deeply honored to launch his inaugural Feminist Frontiers section with path-breaking sociologist Raewyn Connell's essay 'New Maps of Struggle for Gender Justice: Rethinking feminist research on organizations and work' which was a keynote at the GWO Sydney conference. As Raewyn reminds us Gender, Work and Organization was launched in in the global North, in the wake of the women's liberation movement but after a first wave of neoliberal politics. Raewyn starts her essay by situating herself culturally, recognising her upbringing in Australia which is still a colonial settler state. Raewyn proposes an agenda for feminist research in light of growing recognition of feminist thought and activism in the global South, changes in work and organization, especially managerial transformation of organizations and global economic restructuring, and changes in the political arena such as the rise of an authoritarian populism with new patterns of masculinity politics. Crucially, Raewyn speaks: 'I urge the new generation of scholars to be bold. Don't get stuck in familiar models of gender, not even mine. Share your ideas and findings, and work cooperatively. Feminist movements have flourished the more they have worked as collectives, however informal or imperfect' (this issue).

\section{Looking forward}

The future of gender research (Broadbridge and Simpson, 2011) and the mainstreaming of feminist research (Harding, Ford and Fotaki, 2013) has been documented since early interventions decades ago. It seems that a moment in time has come where there is an appetite for political change regarding gender injustice and diversity inequality. Thus in anticipating our future, we hope that we will continue to grow our community of scholars, and engage in consciousness raising not only of the barriers faced and productive advancements made, but of the political importance of ensuring that our collective work seeps into university programmes as well as supporting the Gender, Work and Organization journal. The importance of Gender, Work and Organization in educating students is important for developing this critical masses and we look forward to the ways in which we can support early career academics within the aims and scope of the journal. Our hopes are that the journal embodies resistance against inequality in theory and practice. 
But beyond what is possible in the realm of the textual, we aspire to elucidate and change the conditions that continue to create gendered injustices in our local contexts, institutions and societies - as well as become home to scholars and scholarship that embody the ideas, struggles and approaches that derive from feminist philosophies, theories and practices in the global South. More than ever, the transnationally connected and mobile nature of people who, either out of force or choice, circulate the globe allow us to consider whether and how new regimes of gender/gendered inequalities are taking shape (Ozkazanc-Pan and Calás, 2015). Thus, hat kinds of struggles, resistances and dismantlings are necessary to overcome them in a world on-the-move? Our vision is for Gender, Work \& Organization to create the space for these important conversations and to support a community of gender scholars whose theories and practices can provide the necessary interventions for a feminist future.

Vachhani and Pullen (2018) stress that acts of articulation which recognise multiple, intersectional concerns as well as respecting, acknowledging and embracing the struggles within intersectionality is required. Medina (2013: xi) states that 'Practices of resistance require cultivation to enable us to fully understand exclusion, and to become sensitive to it. However, it requires a commitment to politics that are practised through personal and collective resistance' (Vachhani and Pullen, 2018: 20 on-line first page ). It is at the intersection between the personal and collective that our activism against injustice starts - in our universities, policy offices, in our journals. Organizing against systems that violate, oppress, and discriminate is a challenge, but one that we can do collectively. Feminist social movements can create change in universities and in our scholarly community. Feminist resistance against neoliberalism which threaten our disciplines and our bodies alike is needed. And if our feminisms are different, our need to join forces to fight against our common enemy is critical. We need to build solidarity. We need to call out sexism, misogyny and we need to speak out even when there is a backlash. We will also need to speak out for those who can't. We need to tell feminist stories for others to follow. We need to work differently. But we also need to be mindful of uneven feminist visibilities and bemoaning sexism without action. In a context of \#MeToo, Eva Cox (2018) asks us whether \#MeToo offers the lasting effects required for gender equality. For the risk with \#MeToo is that, like a lot of other protest movements, that it will point out the problem without addressing its underlying causes. Thus we end by asking what future encounters are possible between scholars interested in gender studies? 
As Ozkazanc-Pan (2018) asks that in the midst of the \#MeToo movement sweeping across different societies, what opportunities and challenges exist for changing extant gender structures and systems that have allowed for sexual harassment and assault to take shape? Such a discussion provokes questions around what kinds of feminisms, both as philosophical traditions and as a set of praxis/practices, enable societal and organizational change. Her article focuses explicitly on different notions of agency arriving out of various feminist traditions to underscore possibilities for engaging in such change. Intersectional, decolonial, postcolonial and transnational feminist perspectives are drawn on to suggest that a collectivist approach to agency is necessary for gender system change. Collective feminism is conceptualised as a way to think of agency as a collective strategy and practice that only becomes possible through the work of many. She then discusses this mode of feminism in relation to empowerment and social change toward gender equality. With this collective vision in mind, the next Gender, Work and Organization conference will be held in the University of Kent located in Canterbury, UK and organised by editor Patricia Lewis. The theme for the 2020 conference is Transitions. 


\section{References}

Acker, J. (1998) The future of 'gender and organizations': connections and boundaries. Gender, Work \& Organization, 5, 4, 195-206.,

Ahmed, S. (2006) The nonperformativity of antiracism. Meridians: feminism, race, transnationalism, 7, 1, 104-26.

Broadbridge, A. and Simpson, R., (2011) 25 years on: reflecting on the past and looking to the future in gender and management research. British Journal of Management 22, 3, 47083.

Callon, M. (2007) What does it mean to say that economics is performative? In MacKenzie, D., Muniesa, F. and Siu, L. (eds) Do Economists Make Markets? On the Performativity of Economics, pp. 311-57. Princeton, NJ: Princeton University Press.

Cox, E. (2018) https://theconversation.com/metoo-is-not-enough-it-has-yet-to-shift-thepower-imbalances-that-would-bring-about-gender-equality-92108

De Coster, M. and Zanoni, P. (2018) Governing through accountability: gendered moral selves and the (im) possibilities of resistance in the neoliberal university. Gender, Work \& Organization. DOI:10.1111/gwao.12304

Ferraro, F., Pfeffer, J. and Sutton, R.I. (2005) Economics, language and assumptions: how theories can become self-fulfilling. Academy of Management Review, 30, 1, 8-24.

Ferraro, F., Pfeffer, J. and Sutton, R.I. (2009) How and why theories matter: a comment on Felin and Foss (2009). Organization Science, 20, 3, 669-75.

Fraser, N. (2013) Fortunes of feminism: From state-managed capitalism to neoliberal crisis. Verso Books.

Giroux, H. (2014) https://truthout.org/articles/henry-a-giroux-neoliberalism-democracy-andthe-university-as-a-public-sphere/

Harding, N., Ford, J. and Fotaki, M., (2013) Is the 'F'-word still dirty? A past, present and future of/for feminist and gender studies in Organization. Organization, 20, 1, 51-65 
Holvino, E., (2010) Intersections: The simultaneity of race, gender and class in organization studies. Gender, Work \& Organization, 17, 3, 248-77.

Lewis, P. and Simpson, R. (2017) Hakim Revisited: preference, choice and the postfeminist gender regime. Gender, Work and Organization, 24, 2, 115-33.

Marti, E. and Scherer, A.G. (2016) Financial regulation and social welfare: the critical contribution of management theory. Academy of Management Review, 41, 2, 298-323.

Ozkazanc-Pan, B., (2018) On agency and empowerment in a \#MeToo world. Gender, Work \& Organization. On-line first. https://doi.org/10.1111/gwao.12311

Ozkazanc-Pan, B., and Calás, M. B. (2015). "Transnational approaches to diversity” in R. Bendl, I. Bleijenbergh, E. Henttonen, and A. Mills (Eds.), The Oxford Handbook of Diversity. Oxford, UK: Oxford University Press, pp.376-390

Parker, M., (2014) University, Ltd: Changing a business school. Organization, 21, 2, 281-92.

Rhodes, C., Wright, C. and Pullen, A., (2018) Changing the world? The politics of activism and impact in the neoliberal university. Organization, 25, 1, 139-47.

Runte, M. and Mills, A.J. (2006) Cold war, chilly climate: explaining the roots of gendered discourse in organization and management theory. Human Relations, 59, 5, 695-720.

Vachhani, S.J. and Pullen, A. (2018) Ethics, politics and feminist organizing: Writing feminist infrapolitics and affective solidarity into everyday sexism. Human Relations, p.0018726718780988.

Levin, S. (2018) https://www.theguardian.com/technology/2018/nov/08/google-sexualharassment-policy-overhaul-walkout-

protest?CMP=Share_AndroidApp_Facebook\&fbclid=IwAR00B1Lvo3VW5O2cykrxNXa3nq $\underline{\text { nB7xUgTPriORLKjz3_QEXkjUpHi5hASb0 }}$ 